
TEXT.

\title{
Glacitectonics - a key approach to examining ice dynamics, substrate rheology and ice-bed coupling
}

\author{
Jonathan R. Lee ${ }^{1^{*}}$ and Emrys Phillips ${ }^{2}$ \\ ${ }^{1}$ British Geological Survey, Keyworth, Nottingham, NG12 5GG, UK. \\ ${ }^{2}$ British Geological Survey, Murchison House, West Mains Road, Edinburgh, EH9 3LA, UK. \\ *Corresponding author: J R Lee (Email: jrlee@bgs.ac.uk
}

\begin{abstract}
The role of ice masses within the Earth's climate system and in landscape change is increasingly being recognised within regions that are either currently glaciated or were glaciated during the geological past. There are many different remote and field-based approaches to studying the products of glaciation. One approach - that of glacitectonics, focuses on the styles of deformation and tectonic imprint (folds, fractures, fabrics, foliations and lineations) produced as ice overrides or pushes into pre-existing rocks or sediment. This approach, when used in combination with other types of evidence, can be used to infer ice-dynamics, substrate rheology and ice-bed coupling. Of equal significance is the influence of glacitectonic structure upon the applied properties of glaciated terranes such as ground stability, hydrogeology and fluid migration (e.g. water, gas hydrates and hydrocarbons). This paper provides an introduction to this Special Issue on Glacitectonics, outlining the significance and historical development of this field of glacial geology, before introducing and summarising the contributions that make up the volume.
\end{abstract}

\section{Introduction and importance of glacitectonics}

Deformation of rocks and superficial deposits by tectonic processes occur at a range of scales. The largest and most obvious tectonic processes relate to the development of continental-scale subduction and collision zones at convergent plate boundaries (Dewey and Bird, 1970). However, similar tectonic processes, albeit operating at far smaller spatial scales and reduced pressuretemperature conditions, can occur at the Earth's surface as a glacier or ice sheet pushes into or overrides a pre-existing sequence of sediments and/or bedrock. This phenomenon is referred to as glacitectonics (Banham, 1977; Croot, 1987; van der Meer, 1987; Aber et al., 1989; Aber and Ber, 2007; Phillips and Lee, 2011) and is a process widely recognised by geologists since the mid- to latenineteenth century (Johnstrup, 1874; Reid, 1882). Evidence for glacitectonism can include a wide range of secondary structural features including folds, fractures, fabrics, foliations and lineations that are superimposed upon the primary structure of a rock or sediment (van der Meer, 1993; van der Meer et al., 2003; Evans et al., 2006; Menzies et al., 2010; Phillips et al., 2008).

Glacitectonic processes are increasingly recognised as playing a critical role in the development of complex glacigenic sedimentary sequences and landforms in both modern and ancient glacial environments (Croot, 1988; Hart, 1990; Krüger, 1993; Hambrey and Huddart, 1995; Boulton et al., 1996; Rocha-Campos et al., 2000; Williams et al., 2001; Larson et al., 2003; Evans and Hiemstra, 2005; Le Guerroué et al., 2005; Le Heron et al., 2005; Evans et al., 2006; Lee and Phillips, 2008; ; 
Lee, J.R. and Phillips, E. 2013. Glacitectonics - a key approach to examining ice dynamics, substrate rheology and ice-bed coupling. Proceedings of the Geologists' Association, 124, 731-737. ACCEPTED TEXT.

Phillips et al., 2008; Benediktsson et al., 2010). The study of glacitectonic processes provide valuable insights into the internal (e.g. substrate rheology, temperature and drainage) and external (e.g. climate, mass balance) controls on glacier-induced sediment deformation, and in-turn, their influence on ice mass dynamics (van der Wateren, 1995a; Bennett, 2001; Phillips et al., 2002; Boulton et al., 2004; Thomas et al., 2004; Evans and Hiemstra, 2005; Thomas and Chiverrell, 2007; Benediktsson et al., 2010; Waller et al., 2011; Phillips et al., 2012; Szuman et al., this volume). Recognising and understanding glacitectonic structures and processes is also highly relevant to applied geosciences. Sediment mixing and the presence of glacitectonic structures such as folds and faults can have major implications for ground stability and foundation strength by altering material properties and introducing substrate failure planes (Sauer, 1978; Kurfurst and Dallimore, 1991). For example, there are many documented examples of glacitectonic structures exerting a dominant control on the development and style of landslides (Campbell and Evans, 1990; Stauffer et al., 1990; Lee et al., 2011). Indeed, many large-scale infrastructure developments in areas of formerly glaciated terrain now carry out detailed ground investigations to determine whether or not glacitectonic structures are present in the shallow sub-surface. Glacitectonic structures can also act as fluid migration pathways or reservoir traps for water (Jørgensen and Holm, 1995; Scheytt et al., 2001; Burschil et al., 2012), hydrocarbons (Levell et al., 1988; Huuse et al., 2012) and gas hydrates (Hovland, 1990) and are therefore of importance with respect to hydrogeology, civil engineering, hydrocarbon exploration and Carbon Capture and Storage (CCS).

This Special Issue of Proceedings of the Geologists Association has been compiled following a highly successful workshop held in Sheringham (UK) during September 2011 on the topic of Glacitectonics which examined their glaciological and applied significance. The workshop was organised by the Quaternary Research Association in collaboration with the Glacial Landsystems Working Group (GLWG) and the International Permafrost Association and attracted geologists from Denmark, Iceland, Poland and the UK. The purpose of this Special Issue is to celebrate this workshop by presenting a selection of topical research papers under the general banner of Glacitectonics. In this introduction paper, we provide a historical and methodological context to this highly dynamic field of glacial research as well as summarising the contributions to the Special Issue.

\section{Evolution of Glacitectonic Theory}

The study of glacitectonics is a relatively new phenomenon but has its origins and evolution can ultimately be traced with major historic developments in Geology and Earth Sciences. During much of the eighteenth century, the majority of naturalists and scientists related the geological history of the Earth to the product of a biblical 'Great Flood' described within the Book of Genesis. This includes the products of what we now know to be glacial origin such as moraines, erratics and glacial scour features. However, the eighteenth century marks an important tipping point in scientific philosophy with the emergence of sciences, including Geology and Earth Science, during the socalled 'Age of Enlightenment'. One significant concept to evolve during this era was the realisation that many products of the 'Great Flood' (also known as the 'Diluvial Theory') could be explained by worldly processes that can be interpreted from the rocks and landscape. One of the principal pioneers of this movement was James Hutton who published his geological Theory of the Earth in 1775. Hutton together with several other important naturalists of the late eighteenth and early nineteenth centuries, including Horace-Bénédict de Saussure, Jens Esmarck, Karl Freidrich Schimper 
Lee, J.R. and Phillips, E. 2013. Glacitectonics - a key approach to examining ice dynamics, substrate rheology and ice-bed coupling. Proceedings of the Geologists' Association, 124, 731-737. ACCEPTED TEXT.

and Jean de Charpentier, speculated that glaciers had once covered far more of continental Europe than their current extent. Louis Agassiz took this theory a step further by suggested that glaciers and ice sheets had, within the recent geological past, been far more extensive throughout the northern hemisphere. This Swiss-born geologist also had a significant role to play in introducing the concept of glaciation in Britain. Alongside William Buckland, he toured the Scottish Highlands in 1840, examining landforms and 'recent deposits', concluding that highland areas of Britain and Ireland had acted as dispersal centres for ice masses with trains of sediment emanating away from them into sediment accumulation areas.

Despite the contributions of geologists such as Louis Agassiz and William Buckland the specific processes of erosion and deposition by ice within the landscape remained contentious. Many geologists modified their 'diluvial' views to include the activity of floating ice (i.e. icebergs) and phases of landscape submergence. Arguably the most significant figure in changing this perception was James Geikie who developed the 'land-ice' theory based upon detailed observations made throughout Scotland. His theories and models were published within a number a landmark papers and monographs including three separate editions of book The Great Ice Age and its Relation to the Antiquity of Man published in 1874, 1877 and 1894. Geikie's work was clearly influenced by the earlier studies of Ramsay (1862) who demonstrated that many of the 'rock basins' of Scotland (e.g. U-shaped valleys and fjords) were the product of glacial scouring and erosion. In-turn, the authoritative work of James Geikie influenced many other geologists working not just in the UK, but elsewhere in North America and Europe who examined the landscape and especially 'disturbed' sequences with a fresh perspective. During the late nineteenth and early twentieth century's, disturbed glacial sequences were widely recognised with major studies undertaken in southern Sweden (Torrel, 1872), parts of North America (Gilbert, 1899; Hopkins, 1923) and the classic site of Møens Klint in Denmark (Johnstrup, 1874). In the UK, Clement Reid who undertook the first geological survey of the Cromer District of north Norfolk described in detail the glacial geology of many of the coastal sections and recognised that much of the sequence has been disturbed by ice. He called the deformed sequence the 'Contorted Drift', a phrase that is still used informally to this day, and likened their structure to the action of pushing a book over a table cloth. His findings were published as an Old Series geological map and an accompanying memoir entitled The Geology of the Country around Cromer (Reid, 1882).

The principal pioneer of glacitectonism, however, was George Slater who was the first geologist to employ the phrase glacial tectonics within a landmark paper published in Proceedings of the Geologists Association in 1926 (Slater, 1926). Slater worked extensively in modern glacial environments including Spitsbergen (Slater, 1925) and Switzerland (Slater and Walker, 1929), but he is perhaps most widely recognised for his studies of relict glacial sequences in Canada (Slater, 1927a), the United States (Slater, 1929) and Denmark (Slater, 1928a, b) (Figure 1). He also published widely on glacially-deformed sediments in Britain. These studies include a detailed structural interpretation of the Bride Moraine on the Isle of Man (Slater, 1931) and the Anglian ice margin in the southern part of the Gipping Valley near Ipswich in southern East Anglia (Slater and Layard, 1907; Slater, 1927b). Slater also worked on the famous 'Contorted Drift' sequence of northeast Norfolk which had previously been examined by Charles Lyell and Clement Reid. However, other 
Lee, J.R. and Phillips, E. 2013. Glacitectonics - a key approach to examining ice dynamics, substrate rheology and ice-bed coupling. Proceedings of the Geologists' Association, 124, 731-737. ACCEPTED TEXT.

than a report on a field meeting in Cromer and Norwich (Boswell, 1923) this work and the stunning cross-sections that he drew were never formally published.

Whilst Slater's work was considered by many in the UK to be of only "...ephemeral interest..." (Howarth in Slater, 1926), research elsewhere in Europe continued to gather pace. A particularly significant piece of work was published by Gripp (1929) in which he drew the comparison between relict glacitectonic structures in the geological record, and modern processes occurring within the foreland of Holmströms Glacier on Spitsbergen. Systematic surveying of glacitectonic terrains also began in several European countries including Denmark (Jessen, 1931, 1935, 1936; Gry, 1940; Jessen, 1945), Poland (Lewiński and Różycki, 1929; Czajka, 1931; Dylik, 1961) and the Netherlands (Crommelin and Maarleveld, 1949; Maarleveld, 1953) and has continued to the present day (Overgaard and Jakobsen, 2001; Jakobsen, 2003; Rattas and Kalm, 2004). Similar surveys have also been undertaken in North America and resulted in the publication of a national-scale glacitectonic map (Aber et al., 1995) and several regional-scale data sets from Saskatchewan / Alberta (Byers, 1959; Christiansen and Division, 1961; Kupsch, 1962; Whitaker and Christiansen, 1972) and Yukon (Mackay, 1959; Mackay and Mathews, 1964) territories of western Canada, and North Dakota in the United States (Bluemle and Clayton, 1984).

Much of our modern understanding of glacitectonism stems from the work of Peter Banham (UK) and Asger Berthelsen (Denmark) during the 1970s. Both geologists highlighted the structural similarity between glacier-induced shearing and bedrock deformation structures associated with continental shear zones (Berthelsen, 1973; Banham, 1975, 1977; Berthelsen, 1978). This period also coincides with a marked divergence in the study of glacitectonics with research focussing on the two principal end members: (i) subglacial and (ii) proglacial glacitectonism (Hart et al., 1990).

Banham (1977) introduced the now widely-used phrase glacitectonite, drawing analogies between the products of subglacial glacitectonism and mylonitic metamorphic rocks, suggesting that deformation within subglacially-sheared materials was partitioned between zones where elements of the primary lithology and structure were preserved (exodiamict glacitectonite), and zones where any primary lithology or structure could not be discerned (endodiamict glacitectonite) (Figure 2). The importance of Banham's (1977) observations can perhaps only be fully-rationalised within the context of 'subglacial deformable beds' which has subsequently revolutionised glaciology and glacial geology (Boulton and Jones, 1979; Clark and Walder, 1994; Hart, 1995; Boulton, 1996; Murray, 1997; Evans et al., 2006). This 'paradigm shift' in glaciology (Boulton, 1986) was based upon theoretical and field based models that demonstrated that a component of forward glacier motion was accommodated by deformation within the substrate or subglacial bed (Boulton, 1986; Boulton and Hindmarsh, 1987). Subglacial deformable beds have since been widely recognised or inferred beneath both modern (Alley et al., 1986; Dowdeswell et al., 2004) and ancient ice masses (Hicock et al., 1989; Clark and Walder, 1994; Hart, 2007; Maclachlan and Eyles, 2011). They possess a distinctive glacitectonic structure characterised by a vertical variation in cumulative strain reflected in systematic changes in the style and relative intensity of deformation (Banham, 1977; Hart and Boulton, 1991; Benn and Evans, 1996; Evans et al., 2006). This profile, from the base upwards, comprises: (a) undeformed substrate; (b) 'type B' glacitectonite with non-penetrative deformation (slightly deformed primary structure); (c) 'type $A$ ' glacitectonite with penetrative deformation (widespread shear structures); and (d) diamicton often referred to as either 'deformation till' 
Lee, J.R. and Phillips, E. 2013. Glacitectonics - a key approach to examining ice dynamics, substrate rheology and ice-bed coupling. Proceedings of the Geologists' Association, 124, 731-737. ACCEPTED TEXT.

(Dreimanis, 1988) or 'subglacial traction till'(Evans et al., 2006). Preservation of this idealised profile is dependent upon active accretion of diamicton (d) and the immobilisation of lower strain areas as the base of the deforming layer (a-b boundary) moves upwards (Figure 3). Subsequent studies have shown that the base of the deforming layer and positions of different strain zones within the deforming bed can vary in time and space due to variations in pore-water availability and cumulative strain. This can cause the subglacial bed to lock (stick) and unlock (slip) repeatedly, and has been recognised within the geological record as a mosaic-type partitioning of structural styles (Piotrowski and Tulaczyk, 1999; Piotrowski et al., 2004; Piotrowski et al., 2006; Lee and Phillips, 2008; Phillips et al., 2008; Menzies and Ellwanger, 2011).

Proglacial glacitectonism refers to the large-scale displacement and deformation of either lithified or un-lithified proglacial or sub-marginal materials by stresses applied by active ice (Benn and Evans, 2010). Landform features attributed to this style of glacitectonism have been long-recognised, including hill-hole pairs, composite ridges and thrust-block moraines, cupola hills and mega blocks and rafts (Milthers, 1948; Smed, 1962; Banham, 1975; Ruszczynska-Szenajch, 1987; Aber et al., 1989; Burke et al., 2009) and have been mapped extensively, for example, in Europe (Smed, 1962) and parts of North America (Aber et al., 1995). Various models have been presented to explain the mechanics of proglacial tectonics (Aber, 1982). However, it was Croot (1987) who drew analogues with foreland fold-thrust belts within continental collision zones in his development of a thin-skinned glacitectonic model. In this model, Croot argued that deformation was constrained above a basal décollement surface with lateral stresses producing a series of proglacial imbricate thrust slices and nappes. Whilst a fundamental step forward there were aspects of the model that could not easily be explained, not least the tendency of proglacial landforms to be too large to be produced by the shear stresses commonly observed at ice margins. This led to the conclusion that the force applied by an ice-mass wasn't lateral but rotational, leading to the production of a series of wedges displaced upwards and down-ice by the load of the glacier (Bucher, 1956; Dahlen et al., 1984). This process is now commonly referred to as the gravity spreading model (Rotnicki, 1976; van der Wateren, 1985; Pedersen, 1987; Aber et al., 1989). The styles of deformation produced by proglacial and subglacial glacitectonism are markedly different, and where superimposed, can be used to reconstruct structural frameworks (kinetostratigraphy) relating to different ice-marginal positions (van der Wateren, 1987, 1995a, b; Phillips et al., 2002; Thomas et al., 2004; van der Wateren, 2005; Thomas and Chiverrell, 2007; Phillips et al., 2008; Rijsdijk et al., 2010). However, differentiating specific glacitectonic settings that fall between these end members has proven problematic because at a local-scale, the processes of deformation that exist between various tectonic styles are strikingly similar (Phillips et al., 2007; Benn and Evans, 2010). One such historical debate surrounds whether different types of subglacial diamicton (e.g. melt-out till, lodgement till, subglacial traction till) can be recognised (van der Meer, 1993; McCarroll and Rijsdijk, 2003), or whether all subglacial tills are essentially subglacial traction or deforming bed tills because they are the product of subglacial shearing (van der Meer et al., 2003; Menzies et al., 2006). There has also been considerable research attempting to distinguish between massive diamictons produced by subaqueous and subglacial processes. This relates both to specific examples, for instance the Late Devensian glaciation of the Irish Sea Basin, and to the development of analytical criteria to distinguish between subglacial and waterlain sedimentation (Dreimanis, 1982; McCarroll and Harris, 1992; Hart and Roberts, 1994; Carr, 2001; Lee, 2001; McCarroll, 2001). 
Lee, J.R. and Phillips, E. 2013. Glacitectonics - a key approach to examining ice dynamics, substrate rheology and ice-bed coupling. Proceedings of the Geologists' Association, 124, 731-737. ACCEPTED TEXT.

\section{Contents of the Special Issue}

The eight papers included within this Special Issue serve as an excellent illustration of the breadth of contemporary glacitectonic research and have been arranged thematically to reflect the different areas of this field. The first two papers - by Johnson et al. (this volume) and Lee et al. (this volume), focus on the development of glacitectonic structures and landforms associated with proglacial and sub-marginal glacial environments. Johnson et al. (this volume) present a detailed study on the geomorphology and internal architecture of a Younger Dryas-age submarine push moraine complex from central Sweden. They argue that the moraine complex formed during two distinctive deformation events with ice extending into, and tectonically remobilising, sediments deposited within an adjacent basin. The first advance tectonised pre-existing clays forming an ice-marginal apron composed of successive sub-aquatic debris flows. A subsequent re-advance of the ice-margin led to the detachment and thrusting of sands and the soft-sediment intrusion of clay layers, whilst up-ice, sands and clays were sheared subglacially. This study complements other recent published case studies from Greenland and Svalbard that offer a rare insight into the glacitectonic processes associated with the formation of submarine push moraines. The paper by Lee et al. (this volume) examines the landforms and structural architecture of the Middle Pleistocene-age 'Cromer Ridge' push moraine in north Norfolk, UK. Presenting data from several sites, Lee et al. reconstruct a complex model for the northwards retreat of the ice margin across north Norfolk from a maximum extent located to the south of the previously-known limit. Glacitectonic evidence is used to infer bed conditions - specifically temporal and spatial variability in substrate drainage and rheology, and inturn ice-marginal dynamics during ice-marginal retreat with several phases of rapid advance, stillstand and mass-wastage are identified. The paper argues that the 'Cromer Ridge' is not a single landform as previously defined, but an extensive complex composed of several landform and structural elements created during a highly-dynamic episode of ice-marginal retreat.

The remaining six papers within this Special Issue occur 'up-ice', and correspond to the development and glaciological significance of subglacial shear zones. The papers by Busfield and Le Heron (this volume) and Menzies et al. (this volume) outline evidence for subglacial glacitectonic processes operating during Neoproterozoic and Pliocene glaciations respectively. Busfield and Le Heron (this volume) examine deposits from the Otavi Mountainland, Namibia, that are of Neoproterozoic age and date to the 'Snowball Earth' glaciation of the Gondwana supercontinent. Detailed examination of the sedimentology, structural geology and micromorphology (thin section analysis) of the deposits reveal that sedimentation originally occurred subaqueously in an ice-contact setting, with the sediment-pile subsequently overridden as the ice margin oscillated. The authors develop a classic subglacial deformable bed model with strain partitioned into three ductile and brittle zones that display an overall upwards increase in cumulative strain towards the inferred ice-bed interface. The paper is important because it contributes to the wider understanding of Neoproterozoic palaeogeography of Gondwana and provides insights into the mechanisms of ice sheet behaviour. The micromorphology and glaciological significance of a Pliocene-age diamicton from Northern Ontario, Canada is examined by Menzies et al. (this volume). Detailed descriptions of structures and textures in thin section have led the authors to interpret the diamicton as a subglacial till that formed within a subglacial deforming layer. Critically, quantitative measurements show that the number of edge-to-edge contacts is much lower than local Pleistocene-age tills. It is suggested that the reduced number of grain-contacts could reflect either a high clay matrix or sediment porosity 
Lee, J.R. and Phillips, E. 2013. Glacitectonics - a key approach to examining ice dynamics, substrate rheology and ice-bed coupling. Proceedings of the Geologists' Association, 124, 731-737. ACCEPTED TEXT.

combined with high porewater pressures and low strain rates and may indicate that the till was emplaced under surging or fast ice stream conditions. The paper provides an important insight into glacier dynamics of the Mid-Pliocene James Bay ice lobe, but more generically, the critical link between detailed geological evidence, subglacial processes and glaciodynamics.

The papers by Phillips et al. (this volume), Szuman et al. (this volume), Fleming et al. (this volume) and Phillips and Lee (this volume) discuss glacitectonic evidence from subglacially sheared materials relating to Quaternary glaciations. Phillips et al. (this volume) describe a complex array of structures from western Anglesey, north Wales, attributed to periglacial and subglacial glacitectonic origins. Here, highly brecciated metasedimentary rocks of Cambrian age have been locally remobilised to form a variably thick but extensive regolith. This regolith has been further brecciated and disrupted by involutions, convolute folds and hydrofractures which are considered to be the product of periglacial and active-layer processes. Overlying this regolith is a bedrock-rich diamicton containing hydrofractures, bedrock rafts, brittle and ductile shearing and thrusting that were produced by Irish Sea prior to the deposition of a subglacial till as the island was inundated by the Irish Sea Ice Stream during the Late Devensian glaciation. The paper by Szuman et al. (this volume) examines geological evidence for subglacial processes that were active beneath the Baltic Ice Stream during the Late Weichselian (Devensian) glaciation of central Poland. Through the examination of subglacial landforms preserved within the landscape and sedimentary and structural observations, Szuman and colleagues demonstrate strong thermal and rheological controls on processes operating within the subglacial bed. Four distinctive 'thermo-mechanical facies' (A-D) are identified reflecting variations in subglacial temperature, permafrost and porewater: (A) slow ice flow, dry and cold subglacial conditions; (B) cold but moist subglacial bed; ( $C$ and D) represent wet and warm ice sole. Critically, the spatial distribution of these facies are not considered to be random, with facies $\mathrm{A}$ and $\mathrm{B}$ relating to slow moving, cold-based ice at the marginal and inter-stream areas, and fast-moving, warm-based and well-lubricated ice ( $C$ and $D$ ) forming the axial parts of the ice streams.

Fleming et al. (this volume) utilise structural observations and quantitative fabric data to reconstruct the evolution of a subglacial shear zone superimposed upon a Middle Pleistocene-age sequence of highly-stratified waterlain diamictons in north Norfolk, UK. Fabric data was obtained from examining the anisotropy of magnetic susceptibility (AMS) which revealed a series of magnetic lineations developed parallel to sheath folds and stretching lineations. The authors concluded that following deposition the sequence had been overridden and deformed subglacially on two separate occasions relating to initial (north-to-south stretching) and subsequent (west-to-east stretching) glacitectonic events. Fleming et al. then examine these results within the context of regional ice-flow models and propose several different glaciological scenarios that could explain the evidence.

The paper by Phillips and Lee (this volume) also examines the Middle Pleistocene glacial sequence of north Norfolk focussing on coastal sections between Sheringham and Weybourne. This study investigates several distinctive sand and gravel bodies and their relationship to adjacent till units. Previously, these sand and gravel bodies have been interpreted as large gravitational load structures. However, evidence presented by Phillips and Lee argues that these complex structures may actually be subglacial meltwater channels. Sedimentation within these channels occurred synchronously with the overriding of the sediment pile by ice with a distinctive array of glacitectonic structures superimposed upon both the channels and adjacent tills. Importantly, the study identifies 
Lee, J.R. and Phillips, E. 2013. Glacitectonics - a key approach to examining ice dynamics, substrate rheology and ice-bed coupling. Proceedings of the Geologists' Association, 124, 731-737. ACCEPTED TEXT.

that the draining of the subglacial bed caused the subglacial bed to lock-up and deformation to cease, and the subglacial channel system to become abandoned.

\section{Conclusions}

- This volume includes a number of papers relating to different glaciological aspects of Glacitectonics including subglacial bed processes, proglacial morainic development and glacial landsystem evolution.

- Each paper demonstrates the value of examining structural evidence from deformed glacigenic sequences in reconstructing the complex geological processes that occurred as glacier ice overrode or pushed into pre-existing sediment and / or rock. This evidence is particularly powerful when used in combination with other geological and geomorphological data. Not only is an understanding of glacier-induced deformation important from a glaciological perspective but also to a range of applied users interested in ground stability and fluid mobility (groundwater, hydrocarbons and gas hydrates).

- Detailed studies presented within this volume highlight substrate rheology and water mobility as key controls of both stress and strain rates and in-turn styles of glacier-induced deformation. These vary temporally and spatially reflecting substrate lithology and permeability, water availability and its mobility, and the thermal properties of the ground. Individually and collectively, these variables can exert a strongly influence on ice dynamics especially around ice margins and areas of ice sheets susceptible to fast-flow behaviour (i.e. ice streams).

- Currently, our understanding of stress and strain in glacier-induced deformation is largely relative rather than qualitative. This is partly because of the inaccessibility of the substrate beneath contemporary ice masses, but also because the geotechnical properties of deformed strata from past glaciations reflect post-depositional consolidation rather than the conditions at the time of formation. Attempting to quantify these variables at the time of formation has and will continue to be a major challenge for researchers within the field of Glacitectonics. Not only is this critical to understanding material properties, but they will help establish accurate baseline and boundary conditions which are important for ice sheet and glacier modelling.

\section{Acknowledgements}

The authors wish to thank the contributors and referees for the efforts in helping to compile this Special Issue including Jim Rose, lan Candy and Fiona Isaac for their Editorial support and Jim Rose and Jonathan Ford for their constructive comments of an earlier version of this manuscript. We would also like to acknowledge the attendees of the 2011 Glacitectonics Workshop for making the event such a success.

\section{References}


Lee, J.R. and Phillips, E. 2013. Glacitectonics - a key approach to examining ice dynamics, substrate rheology and ice-bed coupling. Proceedings of the Geologists' Association, 124, 731-737. ACCEPTED TEXT.

Aber, J., Bluemle, J., Brigham-Grette, J., Dredge, L., Sauchyn, D., Ackerman, D., 1995. Glaciotectonic map of North America, 1: 6,500,000. Geological Society of America, Maps and Charts Series.

Aber, J.S., 1982. Model for glaciotectonism. Bulletin of the geological Society of Denmark 30, 79-90.

Aber, J.S., Ber, A., 2007. Glaciotectonism, Developments in Quaternary Science 6. Elsevier, Amsterdam.

Aber, J.S., Croot, D.G., Fenton, M.M., 1989. Glacitectonic Landforms and Strcutures. Kluwer, Dordrecht.

Alley, R., Blankenship, D., Bentley, C., Rooney, S.T., 1986. Deformation of till beneath ice stream B, West Antarctica.

Banham, P.H., 1975. Glaciotectonic structures: a general discussion with particular reference to the contorted drift of Norfolk, In: Wright, A.E., Moseley, F. (Eds.), Ice Ages: Ancient and Modern. Seel House Press, Liverpool, pp. 69-84.

Banham, P.H., 1977. Glaciotectonites in till stratigraphy. Boreas 6, 101-105.

Benediktsson, Í.Ö., Schomacker, A., Lokrantz, H., Ingólfsson, Ó., 2010. The 1890 surge end moraine at Eyjabakkajökull, Iceland: a re-assessment of a classic glaciotectonic locality. Quaternary Science Reviews 29, 484-506.

Benn, D.I., Evans, D.J.A., 1996. The interpretation and classification of subglacially-deformed materials. Quaternary Science Reviews 15, 23-52.

Benn, D.I., Evans, D.J.A., 2010. Glaciers and Glaciation. Hodder Education, London.

Bennett, M.R., 2001. The morphology, structural evolution and significance of push moraines. Earth-Science Reviews 53, 197-236.

Berthelsen, A., 1973. Weichselian Ice Advances and Drift Successions in Denmark.

Berthelsen, A., 1978. The methodology of kineto-stratigraphy as applied to glacial geology. Bulletin of the geological Society of Denmark 27, 25-38.

Bluemle, J.P., Clayton, L., 1984. Large-scale glacial thrusting and related processes in North Dakota. Boreas 13, 279-299.

Boswell, P.G.H., Slater, G., 1923. Whitsuntide excursion to the Cromer and Norwich districts: May 18-23, 1923. Proceedings of the Geologists' Association, 223-232. 
Lee, J.R. and Phillips, E. 2013. Glacitectonics - a key approach to examining ice dynamics, substrate rheology and ice-bed coupling. Proceedings of the Geologists' Association, 124, 731-737. ACCEPTED TEXT.

Boulton, G.S., 1986. A paradigm shift in glaciology. Nature 322.

Boulton, G.S., 1996. Theory of glacial erosion, transport and deposition as a consequence of subglacial sediment deformation. Journal of Glaciology 42, 43-62.

Boulton, G.S., Hindmarsh, R.C.A., 1987. Sediment deformation beneath glaciers: rheology and sedimentological consequences. Journal of Geophysical Research 92, 9059-9082.

Boulton, G.S., Jones, A.S., 1979. Stability of temperate ice caps and ice sheets resting on beds of deformable sediment. Journal of Glaciology 24, 29-43.

Boulton, G.S., van der Meer, J.J.M., Beets, D.J., Hart, J.K., Ruegg, G.H.J., 2004. The sedimentary and structural evolution of a recent push moraine complex: Holmströmbreen, Spitsbergen, pp. 149-180.

Boulton, G.S., Van Der Meer, J.J.M., Hart, J., Beets, D., Ruegg, G.H.J., Van Der Wateren, F.M., Jarvis, J., 1996. Till and moraine emplacement in a deforming bed surge - An example from a marine environment. Quaternary Science Reviews 15, 961-987.

Bucher, W.H., 1956. Role of gravity in orogenesis. Geological Society of America Bulletin 67, 1295-1318.

Burke, H., Phillips, E., Lee, J.R., Wilkinson, I.P., 2009. Imbricate thrust stack model for the formation of glaciotectonic rafts: an example from the Middle Pleistocene of north Norfolk, UK. Boreas 38, 620-637.

Burschil, T., Scheer, W., Kirsch, R., Wiederhold, H., 2012. Hydrogeological characterisation of a glacially affected barrier island-the North Frisian Island of Föhr. Hydrol. Earth Syst. Sci. Discuss 9, 5085-5119.

Busfield, M.E., Le Heron, D.P., this volume. Glacitectonic deformation in the Chuos Formation of northern Namibia: implications for Neoproterozoic ice dynamics. Proceedings of the Geologists' Association.

Byers, A., 1959. Deformation of the Whitemud and Eastend formations near Claybank, Saskatchewan. Canada: sn.

Campbell, I.A., Evans, D.J.A., 1990. Glaciotectonism and landsliding in Little Sandhill Creek, Alberta. Geomorphology 4, 19-36.

Carr, S., 2001. Micromorphological criteria for discriminating subglacial and glacimarine sediments: Evidence from a contemporary tidewater glacier, Spitsbergen. Quaternary International 86, 71-79.

Christiansen, E.A., Division, S.R.C.G., 1961. Geology and ground-water resources of the Regina area, Saskatchewan, Saskatoon, Saskatchewan:. Saskatchewan Research Council, Geology Division. 
Lee, J.R. and Phillips, E. 2013. Glacitectonics - a key approach to examining ice dynamics, substrate rheology and ice-bed coupling. Proceedings of the Geologists' Association, 124, 731-737. ACCEPTED TEXT.

Clark, P.U., Walder, J.S., 1994. Subglacial drainage, eskers, and deforming beds beneath the Laurentide and Eurasian ice sheets. Geological Society of America Bulletin 106, 304-314.

Crommelin, R., Maarleveld, G., 1949. Een nieuwe geologische kaartering van de zuidelijke Veluwe. Tijdsschrift Koninklijk Nederlands Aardrijkskundig Genootschap, 2e Reeks 66, 41-56.

Croot, D., 1988. Glaciotectonics and surging glaciers: a correlation based on Vestspitsbergen, Svalbard, Norway. Glaciotectonics: forms and processes. Rotterdam, AA Balkema, 49-61.

Croot, D.G., 1987. Glacio-tectonic structures - a mesoscale model of thin-skinned thrust sheets. Journal of Structural Geology 9, 797-808.

Czajka, W., 1931. Der schlesische Landrücken: Eine Landeskunde Nordschlesiens. F. Steiner.

Dahlen, F., Suppe, J., Davis, D., 1984. Mechanics of fold-and-thrust belts and accretionary wedges: Cohesive Coulomb theory. Journal of Geophysical Research 89, 10087-10010,10101.

Dewey, J.F., Bird, J.M., 1970. Mountain belts and the new global tectonics. Journal of Geophysical Research 75, 2625-2647.

Dowdeswell, J.A., Cofaigh, C.Ó., Pudsey, C.J., 2004. Thickness and extent of the subglacial till layer beneath an Antarctic paleo-ice stream. Geology 32, 13-16.

Dreimanis, A., 1982. Two origins of the stratified Catfish Creek Till at Plum Point, Ontario, Canada. Boreas 11, 173-180.

Dreimanis, A., 1988. Tills, their genetic terminology and classification, In: Goldthwait, R.P., Matsch, C.L. (Eds.), Genetic Classification of Glacigenic Deposits. Balkema, Rotterdam, pp. 17-93.

Dylik, J., 1961. General Presentation: Guide Book of Excursion C, The Łódz Region, VI INQUA Congress, Warsaw, Poland. Lodz, pp. 7-32.

Evans, D.J.A., Hiemstra, J.F., 2005. Till deposition by glacier submarginal, incremental thickening. Earth Surface Processes and Landforms 30, 1633-1662.

Evans, D.J.A., Phillips, E.R., Hiemstra, J.F., Auton, C.A., 2006. Subglacial till: Formation, sedimentary characteristics and classification. Earth-Science Reviews 78, 115-176.

Fleming, E.J., Stevenson, C.T.E., Petronis, M.S., this volume. New insights into the deformation of a Middle Pleistocene glaciotectonised sequence in Norfolk, England through magnetic and structural analysis.

Proceedings of the Geologists' Association. 
Lee, J.R. and Phillips, E. 2013. Glacitectonics - a key approach to examining ice dynamics, substrate rheology and ice-bed coupling. Proceedings of the Geologists' Association, 124, 731-737. ACCEPTED TEXT.

Gripp, K., 1929. Glaziologische und geologische Ergebnisse der Hambergischen Spitzbergen-Ekspedition 1927. Abh. Naturw. Verein Hamberg 22, 147-247.

Gry, H., 1940. De istektoniske forhold i molerområdet. Meddelelser fra Dansk Geologisk Forening 9, 586-627.

Hambrey, M.J., Huddart, D., 1995. Englacial and proglacial glaciotectonic processes at the snout of a thermally complex glacier in Svalbard. Journal of Quaternary Science 10, 313-326.

Hart, J.K., 1990. Proglacial glaciotectonic deformation and the origin of the Cromer Ridge push morraine, north Norfolk, England. Boreas 19, 165-180.

Hart, J.K., 1995. Subglacial erosion, deposition and deformation associated with deformable beds. Progress in Physical Geography 19, 173-191.

Hart, J.K., 2007. An investigation of subglacial shear zone processes from Weybourne, Norfolk, UK. Quaternary Science Reviews 26, 2354-2374.

Hart, J.K., Boulton, G.S., 1991. The interrelations of glaciotectonic and glaciodepositional processes within the glacial environment. Quaternary Science Reviews 10, 335-350.

Hart, J.K., Hindmarsh, R.C.A., Boulton, G.S., 1990. Styles of subglacial glaciotectonic deformation within the context of the Anglian ice-sheet. Earth Surface Processes and Landforms 15, 227-241.

Hart, J.K., Roberts, D.H., 1994. Criteria to distinguish between subglacial glaciotectonic and glaciomarine sedimentation, I. Deformation styles and sedimentolgy. Sedimentary Geology 91, 191-213.

Hicock, S.R., Kristjansson, F.J., Sharpe, D.R., 1989. Carbonate till as a soft bed for Pleistocene ice streams on the Canadian Shield north of Lake Superior. Canadian Journal of Earth Sciences 26, 2249-2254.

Hovland, M., 1990. Suspected gas-associated clay diapirism on the seabed off Mid Norway. Marine and Petroleum Geology 7, 267-276.

Huuse, M., Le Heron, D., Dixon, R., Redfern, J., Moscariello, A., Craig, J., 2012. Glaciogenic reservoirs and hydrocarbon systems: an introduction. Geological Society, London, Special Publications 368, 1-28.

Jakobsen, P., 2003. GIS based map of glaciotectonic phenomena in Denmark. Geological Quarterly 47, 331-338.

Jessen, A.H., 1931. Lønstrup Klint. Danmarks Geologiske Undersøgelse.

Jessen, A.H., 1935. Beskrivelse til geologisk kort over Danmark. Kortbladet Haderslev. Danmarks Geologiske Undersøgelse. 
Lee, J.R. and Phillips, E. 2013. Glacitectonics - a key approach to examining ice dynamics, substrate rheology and ice-bed coupling. Proceedings of the Geologists' Association, 124, 731-737. ACCEPTED TEXT.

Jessen, A.H., 1936. Vendsyssels Geologi. Danmarks Geologiske Undersøgelse.

Jessen, A.H., 1945. Beskrivelse til geologisk kort over Danmark. Kortbladet Sønderborg. Danmarks Geologiske Undersøgelse.

Johnson, M.D., Benediktsson, Í.Ö., Björklund, L., this volume. The Ledsjö end moraine-a subaquatic push moraine composed of glaciomarine clay in central Sweden. Proceedings of the Geologists' Association.

Johnstrup, F., 1874. Ueber die Lagerungsverhältnisse und die Hebungsphänomene in den Kreidefelsen auf Möen und Rügen. Zeitschrift der deutschen geologischen Gesellschaft 26, 533-585.

Jørgensen, N.O., Holm, P.M., 1995. Strontium-isotope studies of chloride-contaminated groundwater, Denmark. Hydrogeology Journal 3, 52-57.

Krüger, J., 1993. Moraine-ridge formation along a stationary ice front in Iceland. Boreas 22, 101-109.

Kupsch, W., 1962. Ice-thrust ridges in western Canada. The Journal of Geology, 582-594.

Kurfurst, P., Dallimore, S., 1991. Engineering geology of nearshore areas off Richards Island, NWT: a comparison of stable and actively eroding coastlines. Canadian Geotechnical Journal 28, 179-188.

Larson, G.J., Ehlers, J., Gibbard, P.L., 2003. Large-scale glaciotectonic deformation in the Great Lakes basin, USA and Canada. Boreas 32, 370-385.

Le Guerroué, E., Allen, P., Cozzi, A., 2005. Two distinct glacial successions in the Neoproterozoic of Oman. GeoArabia 10, 17-34.

Le Heron, D.P., Sutcliffe, O.E., Whittington, R.J., Craig, J., 2005. The origins of glacially related soft-sediment deformation structures in Upper Ordovician glaciogenic rocks: Implication for ice-sheet dynamics. Palaeogeography, Palaeoclimatology, Palaeoecology 218, 75-103.

Lee, J.R., 2001. Genesis and palaeogeographical significance of the Corton Diamicton (basal member of the North Sea Drift Formation), East Anglia, U.K. Proceedings of the Geologists' Association 112, 29-43.

Lee, J.R., Pennington, C.V.L., Hobbs, P.R.N., 2011. Trimingham: structural architecture of the Cromer Ridge push moraine and controls on landslide geohazards, In: Phillips, E.R., Lee, J.R., Evans, H.M. (Eds.), Glacitectonics - Field Guide. Quaternary Research Association, Pontypool, pp. 217-228.

Lee, J.R., Phillips, E.R., 2008. Progressive soft sediment deformation within a subglacial shear zone--a hybrid mosaic-pervasive deformation model for Middle Pleistocene glaciotectonised sediments from eastern England. Quaternary Science Reviews 27, 1350-1362. 
Lee, J.R. and Phillips, E. 2013. Glacitectonics - a key approach to examining ice dynamics, substrate rheology and ice-bed coupling. Proceedings of the Geologists' Association, 124, 731-737. ACCEPTED TEXT.

Lee, J.R., Phillips, E.R., Booth, S.J., Rose, J., Jordan, H.M., Pawley, S.M., Warren, M., Lawley, R.S. this volume. A polyphase glacitectonic model for ice-marginal retreat and terminal moraine development: the Middle Pleistocene British Ice Sheet, northern Norfolk, UK. Proceedings of the Geologists Association.

Levell, B.K., Braakman, J.H., Rutten, K.W., 1988. Oil-bearing sediments of Gondwana glaciation in Oman. AAPG Bulletin 72, 775-796.

Lewiński, J., Różycki, S., 1929. Dwa profile geologiczne przez Warszawę. Sprawozd. z posiedzeń Tow. Nauk. Warsz. Wydz. III Nauk. Matm. i Przyrod 22, 1-3.

Maarleveld, G., 1953. Standen van het landijs in Nederland. Boor en Spade 6, 95-105.

Mackay, J.R., 1959. Glacier ice-thrust features of the Yukon coast. Geographical Bulletin 13, 5-21.

Mackay, J.R., Mathews, W.H., 1964. The role of permafrost in ice-thrusting. Journal of Geology 72, 378-380.

Maclachlan, J.C., Eyles, C.H., 2011. Subglacial deforming bed conditions recorded by late Quaternary sediments exposed in Vineland Quarry, Ontario, Canada. Sedimentary Geology 238, 277-287.

McCarroll, D., 2001. Deglaciation of the Irish Sea Basin: a critique of the glaciomarine hypothesis. Journal of Quaternary Science 16, 393-404.

McCarroll, D., Harris, C., 1992. The glacigenic deposits of western Lleyn, north Wales: terrestrial or marine? Journal of Quaternary Science 7, 19-29.

McCarroll, D., Rijsdijk, K.F., 2003. Deformation styles as a key for interpreting glacial depositional environments. Journal of Quaternary Science 18, 473-489.

Menzies, J., Ellwanger, D., 2011. Insights into subglacial processes inferred from the micromorphological analyses of complex diamicton stratigraphy near Illmensee-Lichtenegg, Höchsten, Germany. Boreas 40, 271288.

Menzies, J., Gao, C., Kodors, C., this volume. Microstructural analyses of a Middle Pliocene till from the James Bay Lowlands, Canada-evidence of "potential" fast ice streaming. Proceedings of the Geologists' Association.

Menzies, J., Meer, J.J.M.v.d., Domack, E., Wellner, J.S., 2010. Micromorphology: as a tool in the detection, analyses and interpretation of (glacial) sediments and man-made materials. Proceedings of the Geologists' Association 121, 281-292.

Menzies, J., van der Meer, J.J.M., Rose, J., 2006. Till - as a glacial "tectomict", its internal architecture, and the development of a "typing" method for till differentiation. Geomorphology 75, 172-200.

Milthers, V., 1948. Det danske istidslandskabs terrænformer og deres opståen. Danmarks Geologiske Undersøgelse, III, Række 28, 234.

Murray, T., 1997. Assessing the paradigm shift: deformable glacier beds. Quaternary Science Reviews 16, 995 1016.

Overgaard, T., Jakobsen, P.R., 2001. Mapping of glaciotectonic deformation in an ice marginal environment with ground penetrating radar. Journal of Applied Geophysics 47, 191-197. 
Lee, J.R. and Phillips, E. 2013. Glacitectonics - a key approach to examining ice dynamics, substrate rheology and ice-bed coupling. Proceedings of the Geologists' Association, 124, 731-737. ACCEPTED TEXT.

Pedersen, S.A.S., 1987. Comparative studies of gravity tectonics in Quaternary sediments and sedimentray rocks related to fold belts, In: Jones, M.E., Preston, R.M.F. (Eds.), Sediment Deformation Mechanisms. Geological Society of London, Special Publication 29, pp. 43-65.

Phillips, E., Lee, J.R., 2011. Description, measurement and analysis of glacitectonically deformed sequences, In: Phillips, E., Lee, J.R., Evans, H. (Eds.), Glacitectonics : field guide. Quaternary Research Association, pp. 5-31.

Phillips, E., Lee, J.R., this volume. Development of a subglacial drainage system and its effect on glacitectonism within the polydeformed Middle Pleistocene (Anglian) glacigenic sequence of north Norfolk, Eastern England. Proceedings of the Geologists' Association.

Phillips, E., Lee, J.R., Burke, H., 2008. Progressive proglacial to subglacial deformation and syntectonic sedimentation at the margins of the Mid-Pleistocene British Ice Sheet: evidence from north Norfolk, UK. Quaternary Science Reviews 27, 1848-1871.

Phillips, E., Lee, J.R., Riding, J.B., Kendall, R., Hughes, L., this volume. Periglacial disruption and subsequent glacitectonic deformation of bedrock: an example from Anglesey, North Wales, UK. Proceedings of the Geologists' Association.

Phillips, E., Merritt, J., Auton, C., Golledge, N., 2007. Microstructures in subglacial and proglacial sediments: understanding faults, folds and fabrics, and the influence of water on the style of deformation. Quaternary Science Reviews 26, 1499-1528.

Phillips, E.R., Evans, D.J.A., Auton, C.A., 2002. Polyphase deformation at an oscillating ice margin following the Loch Lomond Readvance, central Scotland, UK. Sedimentary Geology 149, 157-182.

Piotrowski, J.A., Larsen, N.K., Junge, F.W.F.W., 2004. Reflections on soft subglacial beds as a mosaic of deforming and stable spots. Quaternary Science Reviews 23, 993-1000.

Piotrowski, J.A., Larsen, N.K., Menzies, J., Wysota, W., 2006. Formation of subglacial till under transient bed conditions: Deposition, deformation, and basal decoupling under a Weichselian ice sheet lobe, central Poland. Sedimentology 53, 83-106.

Piotrowski, J.A., Tulaczyk, S., 1999. Subglacial conditions under the last ice sheet in northwest Germany: icebed separation and enhanced basal sliding? Quaternary Science Reviews 18, 737-751.

Rattas, M., Kalm, V., 2004. Glaciotectonic deformation patterns in Estonia. Geological Quarterly 48, 15-22.

Reid, C., 1882. The geology of the country around Cromer. H.M.S.O, London.

Rijsdijk, K.F., Warren, W.P., van der Meer, J.J.M., 2010. The glacial sequence at Killiney, SE Ireland: terrestrial deglaciation and polyphase glacitectonic deformation. Quaternary Science Reviews 29, 696-719.

Rocha-Campos, A., Canuto, J.R., dos Santos, P.R., 2000. Late Paleozoic glaciotectonic structures in northern Paraná Basin, Brazil. Sedimentary Geology 130, 131-143.

Rotnicki, K., 1976. The theoretical basis for and a model of glaciotectonic deformation. Quaestiones Geographicae 3, 103-139.

Ruszczynska-Szenajch, H., 1987. The origin of glacial rafts: detachment, transport, deposition. Boreas 16, 101112. 
Lee, J.R. and Phillips, E. 2013. Glacitectonics - a key approach to examining ice dynamics, substrate rheology and ice-bed coupling. Proceedings of the Geologists' Association, 124, 731-737. ACCEPTED TEXT.

Sauer, E.K., 1978. The engineering significance of glacier ice-thrusting. Canadian Geotechnical Journal 15, 457472.

Scheytt, T., Grams, S., Rejman-Rasinski, E., Heberer, T., Stan, H.J., 2001. Pharmaceuticals in groundwater: clofibric acid beneath sewage farms south of Berlin, Germany, ACS Symposium Series. ACS Publications, pp. 8499.

Slater, G., 1925. Observations on the Nordenskiöld and neighboring glaciers of Spitsbergen, 1921. The Journal of Geology, 408-446.

Slater, G., 1926. Glacial tectonics as reflected in disturbed drift deposits. Proceedings of the Geologists' Association 37, 392-400.

Slater, G., 1927a. Structure of the Mud Buttes and Tit Hills in Alberta. Bulletin of the Geological Society of America 38.

Slater, G., 1927b. Studies in the drift deposits of the south-west part of Suffolk: the stucture of the distrubed deposits in the lower part of the Gipping Valley near Ipswich. . Proceedings of the Geologists' Association 38, 157-216.

Slater, G., 1928a. The Disturbed Glacial Deposits in the Neighbourhood of Lønstrup, near Hjørring, North Denmark. Transactions of the Royal Society of Edinburgh 55, 303-315.

Slater, G., 1928b. The Structure of the Disturbed Deposits of Møens Klint, Denmark. Transactions of the Royal Society of Edinburgh 55, 289-902.

Slater, G., 1929. 1. The Structure of the Drumlins Exposed on the South Shore of Lake Ontario. University of the state of New York.

Slater, G., 1931. The structure of the Bride moraine, Isle of Man, Proceedings of the Liverpool Geological Society, pp. 184-196.

Slater, G., Layard, N., 1907. Excursion to Ipswich and Claydon. Proceedings of the Geologists' Association 20, 186-192.

Slater, G., Walker, G., 1929. Studies on the Rhone Glacier, 1927 the relationship between the average air temperature and the rate of melting of the surface of the glacier. Quarterly Journal of the Royal Meteorological Society 55, 385-393.

Smed, P., 1962. Studier over den fynske øgruppes glaciale landskabsformer. Meddelelser fra Dansk Geologisk Forening 15, 1-74.

Stauffer, M.R., Gendzwill, D.J., Sauer, E.K., 1990. Ice-thrust features and the Maymount landslide in the North Saskatchewan River Valley. Canadian Journal of Earth Sciences 27, 229-242.

Szuman, I., Ewertowski, M., Kasprzak, L., this volume. Thermo-mechanical facies representative of fast and slow flowing ice sheets: the Weichselian ice sheet, a central west Poland case study. Proceedings of the Geologists' Association.

Thomas, G.S.P., Chiverrell, R.C., 2007. Structural and depositional evidence for repeated ice-marginal oscillation along the eastern margin of the Late Devensian Irish Sea Ice Stream. Quaternary Science Reviews 26, 2375-2405. 
Lee, J.R. and Phillips, E. 2013. Glacitectonics - a key approach to examining ice dynamics, substrate rheology and ice-bed coupling. Proceedings of the Geologists' Association, 124, 731-737. ACCEPTED TEXT.

Thomas, G.S.P., Chiverrell, R.C., Huddart, D., 2004. Ice-marginal depositional responses to readvance episodes in the Late Devensian deglaciation of the Isle of Man. Quaternary Science Reviews 23, 85-106.

Torrel, O., 1872. Undersökningar öfver istiden. Kungliga Vetenskapsakademiens Förhandlingar 29, 10.

van der Meer, J.J.M., 1993. Microscopic evidence of subglacial deformation. Quaternary Science Reviews 12, 553-587.

van der Meer, J.J.M., Menzies, J., Rose, J., 2003. Subglacial till: the deforming glacier bed. Quaternary Science Reviews 22, 1659-1685.

van der Meer, J.J.M. (Ed). 1987. Tills and Glaciotectonics. A.A. Balkema, Rotterdam.

van der Wateren, F.M., 1985. A model of glacial tectonics, applied to the ice-pushed ridges in the Central Netherlands. Geological Society of Denmark Bulletin 34, 55-74.

van der Wateren, F.M., 1987. Structural geology and sedimentation of the Dammer Berge push moraine, FRG., In: van der Meer, J.J.M. (Ed.), Tills and Glaciotectonics. Balkema, Rotterdam.

van der Wateren, F.M., 1995a. Processes of glaciotectonism, In: Menzies, J. (Ed.), Glacial Environments: Processes, Sediments and Landforms. Pergamon, Oxford, pp. 309-335.

van der Wateren, F.M., 1995b. Structural geology and sedimentology of push moraines. Mededelingen Rijks Geologische Dienst Nr 54.

van der Wateren, F.M., 2005. Ice-marginal terrestrial landsystems: Southern Scandinavian Ice Sheet Margin, In: Evans, D.J.A. (Ed.), Glacial Landsystems. Hodder Arnold, London, pp. 166-203.

Waller, R., Phillips, E., Murton, J., Lee, J., Whiteman, C., 2011. Sand intraclasts as evidence of subglacial deformation of Middle Pleistocene permafrost, North Norfolk, UK. Quaternary Science Reviews 30, 3481-3500.

Whitaker, S., Christiansen, E., 1972. The Empress Group in southern Saskatchewan. Canadian Journal of Earth Sciences 9, 353-360.

Williams, G., Brabham, P., Eaton, G., Harris, C., 2001. Late Devensian glaciotectonic deformation at St Bees, Cumbria: a critical wedge model. Journal of the Geological Society 158, 125-135.

\section{Figure Captions}


Lee, J.R. and Phillips, E. 2013. Glacitectonics - a key approach to examining ice dynamics, substrate rheology and ice-bed coupling. Proceedings of the Geologists' Association, 124, 731-737. ACCEPTED TEXT.

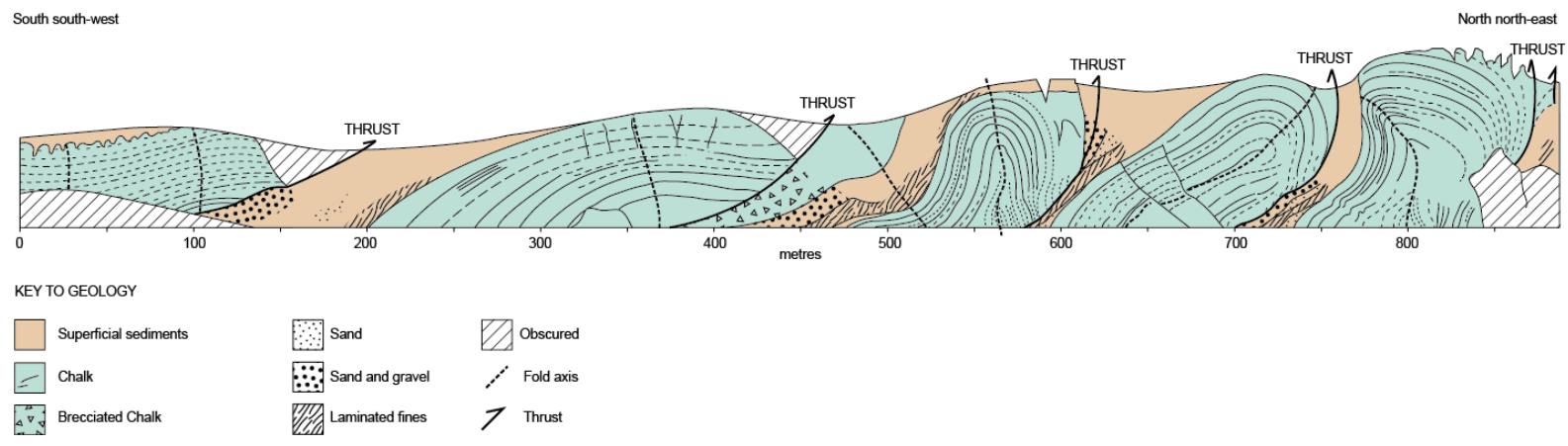

Figure 1. Structural interpretation (with modifications) of the classic Møens Klint site in Denmark by Slater (1928b). Unfortunately, this work attracted controversy with accusation of plagiarism and misrepresentation by a Danish colleague (Jessen, 1931).

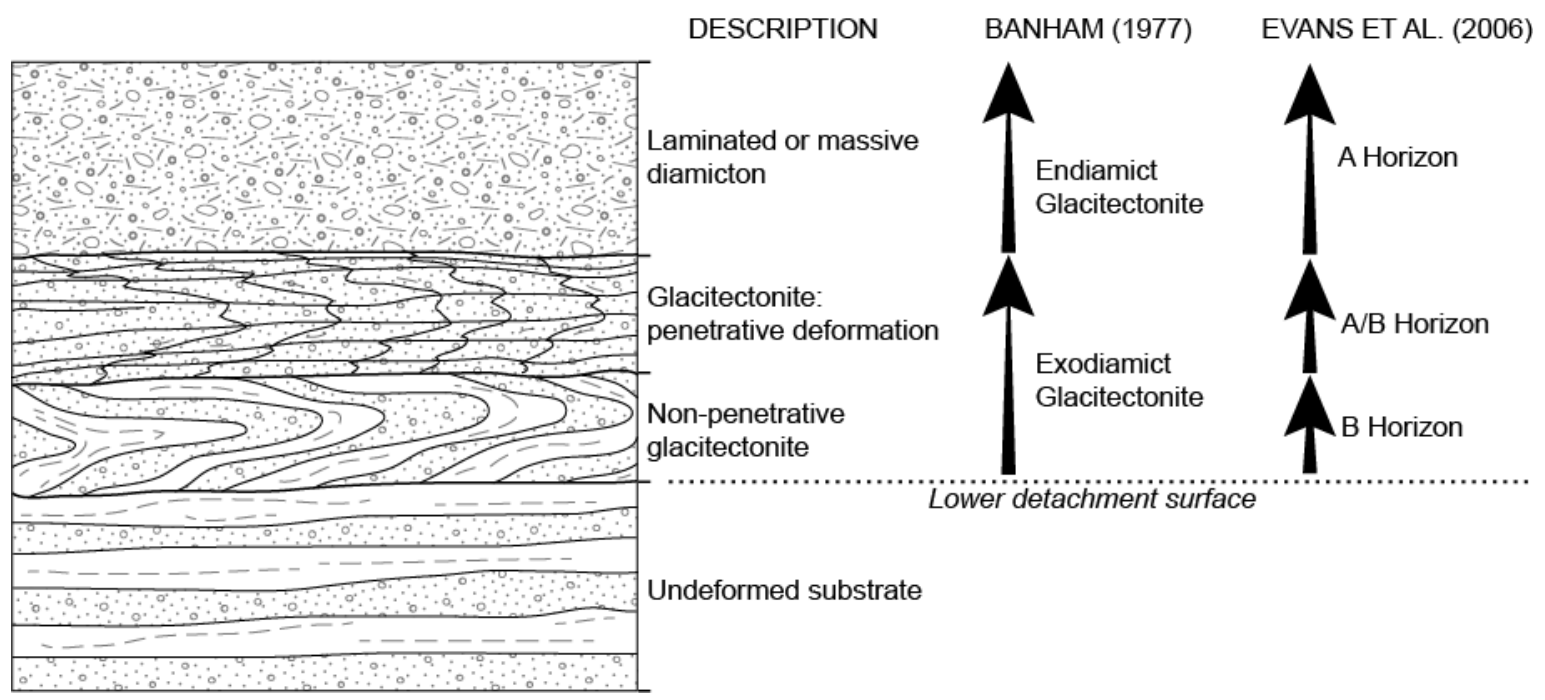

Figure 2. The development of glacitectonites within glacially-deformed materials with the descriptive terminology and nomenclature of Banham (1977) and Evans et al. (2006). 
Lee, J.R. and Phillips, E. 2013. Glacitectonics - a key approach to examining ice dynamics, substrate rheology and ice-bed coupling. Proceedings of the Geologists' Association, 124, 731-737. ACCEPTED TEXT.

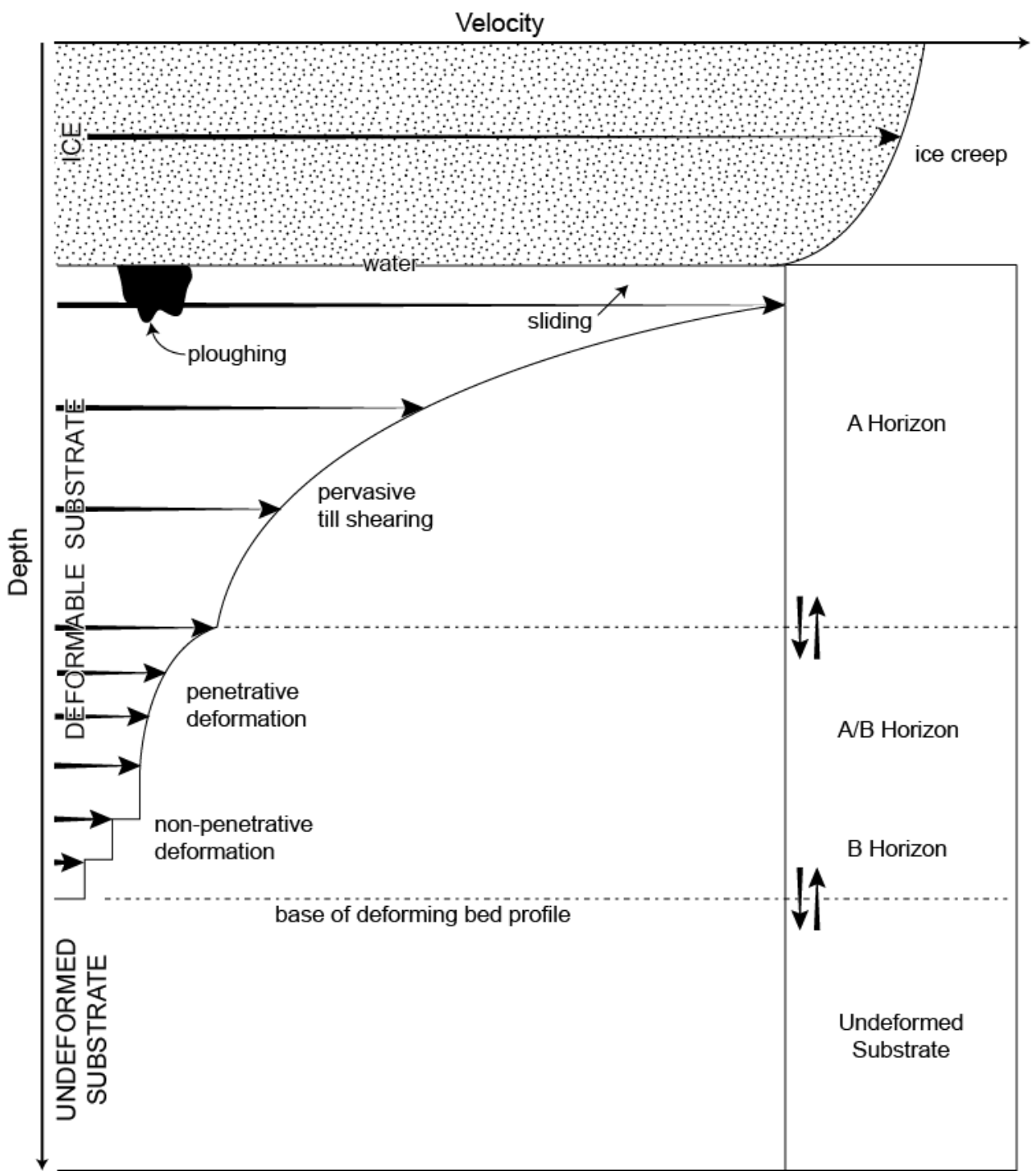

Figure 3. The 'subglacial deforming bed' model after Evans et al. (2006). 